\title{
Model Pembelajaran Berbasis Karakter Konservasi untuk Anak Usia Dini
}

\section{Fitriyannisa ${ }^{1}$, Anak Agung Gede Agung2, I Made Tegeh ${ }^{3}$}

1,2,3Program Studi Pendidikan Dasar, Universitas Pendidikan Ganesha, Singaraja

\section{A R T I CLE I N F O}

Article history:

Received 27 Januari 2021

Revised 13 Maret 2021

Accepted 08 April 2021

Available online 25 April 2021

Kata Kunci:

model, karakter, konservas

Keywords:

model, conservation, character

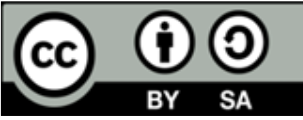

This is an open access article under the CC BY-SA license.

Copyright $($ Universitas Pendidikan Ganesha. All rights reserved.

\begin{abstract}
A B S T R A K
Kurangnya pemahaman anak terhadap karakter konservasi yang disebabkan oleh salah satunya adalah kurang tepatnya pendidik dalam memilih model, metode, strategi atau pendekatan pembelajaran yang sesuai dengan materi pembelajaran. Penelitian ini bertujuan untuk mengembangkan model pembelajaran berbasis karakter konservasi untuk Anak Usia Dini kelompok B. Jenis penelitian ini adalah penelitian pengembangan, prosedur penelitian pengembangan menggunakan model ADDIE yaitu: tahap analisis, desain, pengembangan, implementasi, dan evaluasi. Penelitian ini melibatkan siswa kelompok B. Data dikumpulkan dengan menggunakan instrumen angket. Teknik analisis data menggunakan analisis deskriptif kualitatif dan analisis deskriptif kuantitatif. Hasil penelitian menemukan bahwa hasil uji ahli isi diperoleh persentase skor $83,70 \%$ dengan kualifikasi baik, persentase skor hasil uji perorangan $85.66 \%$ dengan kualifikasi sangat baik. Sehingga, model pembelajaran ini dinilai layak digunakan dalam pembelajaran. Implikasi penelitian ini diharapkan memberikan dampak pada karakter anak menjadi lebih baik.
\end{abstract}

\begin{abstract}
A B S T R A C T
One of the causes of the lack of children's understanding of the character of conservation is the lack of accuracy of educators in choosing models, methods, strategies or learning approaches that are in accordance with the learning materials. This study aims to develop a conservation character-based learning model for Early Childhood Group B. This type of research is development research, development research procedures using the ADDIE model are: analysis, design, development, implementation, and evaluation stages. This study involved students in group B. Data were collected using a questionnaire instrument. The data analysis technique used qualitative descriptive analysis and quantitative descriptive analysis. The results of the study found that the results of the content expert test obtained a percentage score of $83.70 \%$ with good qualifications, the percentage score of individual test results was $85.66 \%$ with very good qualifications. Thus, this learning model is considered suitable for use in learning. The implications of this research are expected to have an impact on the character of children for the better.
\end{abstract}

\section{Pendahuluan}

Pembentukan perilaku dalam melestarikan karakter konservasi bisa dimulai sejak usia dini. Mengembangkan karakter pada anak usia dini memerlukan usaha yang maksimal dan konsisten (Juanda, 2019; Ramdhani et al., 2019). Salah satu caranya adalah dengan menanamkan nilai-nilai karakter pada anak usia dini melaui lembaga-lembaga pendidikan di sekolah (Prasanti \& Fitrianti, 2018; Ramdhani et al., 2019). Mengembangkan karakter anak diperlukan terpenuhinya tiga kebutuhan dasar anak yaitu Maternal Bonding, rasa aman, serta stimulasi fisik dan mental (Ansori, 2021; Ramdan \& Fauziah, 2019; Yulianti et al., 2014). Pendidikan karakter merupakan pendidikan yang berkaitan dengan pengembangan nilai-nilai, kebiasaan-kebiasaan yang baik, dan sikap yang positif guna mewujudkan individu yang dewasa dan bertanggung jawab (Pitaloka et al., 2021; Rosikum, 2018). Salah satu karakter yang terabaik penanamannya oleh para pendidik di sekolah adalah karakter konservasi atau karakter peduli lingkungan

Copyright $($ C Universitas Pendidikan Ganesha. All rights reserved 
(Ridlo \& Irsadi, 2012). Konferensi PBB tentang lingkungan hidup di Stockholm Swedia pada tanggal 15 Juni 1972 diadakan karena dunia mencemaskan akan kerusakan lingkungan (Ridlo \& Irsadi, 2012). Era globalisasi membuat manusia seakan-akan lupa akan pentingnya lingkungan dalam kehidupannya karena mereka kurang puas terhadap sesuatu yang dimilikinya. Mereka mengeksploitasi alam secara besarbesaran hanya untuk memperkaya diri sehingga mereka lupa untuk menjaga keseimbangan alam yang ada, sehingga kerusakan lingkungan terjadi hampir di seluruh wilayah. Karakter konservasi/peduli lingkungan oleh banyak kalangan telah memudar dan tidak memeperhatikan lagi apa dampak perbuatan mereka terhadap lingkungan hidup. Maka dari itu, kepedulian terhadap lingkungan harus di tanamkan keanak sejak usia dini (Ridlo \& Irsadi, 2012).

Kerusakan lingkungan telah terjadi di sekolah dan lingkungan sekitar, karakter konservasi anak masih sangat minim, dilihat dari fakta-fakta di lapangan seperti masih banyaknya anak-anak membuang sampah sembarangan, mencoret- coret meja atau dinding, tidak mematikan keran setelah mencuci tangan, belum mampu menyiram dan merawat tanaman, dan belum mampu merapikan alat dan bahan setelah melakukan kegiatan pembelajaran (Taufiq et al., 2014). Hal ini disebabkan karena guru terlalu pasif, kurang menekankan pentingnya karakter konservasi terhadap anak, aturan yang di berikan oleh guru kurang jelas, dan guru kurang menceritakan tentang akibat dari perilaku-perilaku yang menyimpang diatas, serta guru kurang memberikan kesempatan kepada anak untuk mengeksplor pengetahuannya sendiri. Karakter peduli lingkungan untuk anak usia dini dapat dikembangkan dengan menanamkan nilainilai konservasi sebagai upaya mengatasi masalah kerusakan lingkungan. Menurut Hidayat dalam Ekowati, Et al., (2012) jika karakter anak telah terbentuk sejak kecil mulai dari lingkungan social sampai sekolah dasar, maka generasi masyarakat Indonesia akan menjadi manusia-manusia yang berkarakter yang dapat menjadi penerus bangsa demi terciptanya masyarakat yang adil, jujur, dan bertanggungjawab. Konservasi adalah pelestarian atau perlindungan. Secara harfiah, konservasi berasal dari bahasa inggris conservation yang artinya pelestarian atau perlindungan (Leksono et al., 2013). Pendapat lain menyatakan konservasi adalah upaya pemeliharaan dan perlindungan sesuatu secara teratur untuk mencegah kerusakan dengan cara memperbaiki, mengawetkan, dan melestarikannya. Oleh karena itu konservasi merupakan upaya yang dilakkukan manusia untuk melestarikan atau melindungi alam agar tetap terjaga kelestariannya.

Penanaman pendidikan karakter di sekolah pada lembaga pendidikan anak usia dini khususnya TK Tunas Harapan Maju diperlukan upaya yang maksimal, maka salah satu upaya yang dapat dilakukan adalah dengan menerapkan model pembelajaran berbasis konservasi (Amalia \& Bintari, 2016). Dilihat dari hasil observasi dan wawancara penulis di lapangan, guru TK Tunas Harapan Maju mengatakan bahwa di sekolah ini belum pernah menerapkan model pembelajaran berbasis karakter konservasi, dan di sekolah ini masih banyak anak-anak yang belum paham tentang bagaimana menjaga lingkungan dengan baik, maka dari itu guru merasa sangat perlu mengembangkan model pembelajaran berbasis konservasi agar dapat membentuk anak-anak yang memiliki karakter peduli dan cinta lingkungan. Model pembelajaran berbasis karakter konservasi adalah model pembelajaran yang berprinsip pada pembelajaran karakter yang menunjukkan kepeduliannya terhadap lingkungannya (Sadia, 2013; Yulianti et al., 2014). Model pembelajaran berbasis karakter dikembangkan untuk mengoptimalkan seluruh potensi anak. Aktifitas pembelajaran dilakukan dengan mengidentifikasi nilai nilai karakter peduli lingkungan seperti nilai karakter religious, jujur, cerdas adil, tanggung jawab, peduli, toleran, santun (Hidayah, 2015; Juanda, 2019; Nurohmah \& Dewi, 2021). Model ini mendukung pengembangan karakter dengan lingkungan sekitarnya. Model pembelajaran berbasis karakter konservasi ini merupakan suatu rencana atau pola pembelajaran yang menitikberatkan pada penanaman nilai-nilai konservasi dan peningkatan karakter peduli lingkungan untuk anak (Muhamad Nova, 2017; Rohmanurmeta, 2019).

Makna konservasi dapat meliputi seluruh kegiatan pemeliharaan sesuai dengan situasi dan kondisi setempat. Nilai-nilai koservasi yang perlu ditumbuhkembangkan yaitu nilai menanam, memanfaatkan, melestarikan, dan mempelajari dalam arti fisik dan non-fisik lingkungan (Khusniati, 2014). Kegiatan utama dalam model pembelajaran ini adalah pengenalan nilai-nilai moral yang diterapkan melalui kegiatan-kegiatan pembiasaan yang dilakukan secara terprogram yang sering di lakukan berulang-ulang, seperti contoh; mengajak anak merawat tanaman, membuang sampah pada tempatnya, berbaris sebelum masuk ruang kelas untuk mengajarkan budaya antri, berdoa sebelum dan sesudah kegiatan, mengucapkan salam bila bertemu dengan orang lain, membersihkan ruang kelas tempat belajar dan memanfaatkan bahan alam sebagai bahan kegiatan (Juanda, 2019; Khusniati, 2014; Na'imah et al., 2020). Selain itu dalam pengembangan model pembelajaran ini perlu kegiatan yang melibatkan orang tua (parenting) karena keterlibatan orang tua sangat penting terutama dalam pendidikan anak usia dini, kerjasama orang tua dengan sekolah adalah hal mutlak untuk mencapai perkembangan seluruh aspek perkembangan anak (Syahrul \& Nurhafizah, 2021; Wisnu Budi Wijaya, 2019). 
Temuan penelitian sebelumnya model pembelajaran berbasis konservasi $\mathrm{n}$ efektif digunakan dalam perkembangan karakter peduli lingkungan anak (Purnomo \& Sukarjo, 2020). Temuan lain menyatakan pembelajaran konstektual dapat dilaksanakan dengan empat tahap dengan fokus yang berbeda, sebagian besar siswa sangat antusias untuk mengikuti setiap tahap pembelajaran akan tetapi terdapat kendala dalam hal peraturan waktu yang membuat siswa menjadi tidak bersemangat. Oleh karena itu dapat disimpulkan model pembelajaran berbasis konservasi valid dan efektif untuk mengembangkan karakter peduli lingkungan pada anak usia dini. Model pembelajaran berbasis konservasi yang dikembangkan pada penelitian ini terkait dengan karakter, hal ini menjadi perberbedaan dari penelitian sebelumnya. Tujuan penelitian ini mengembangankan model pembelajaran berbasis karakter konservasi untuk anak kelompok B.

\section{Metode}

Jenis penelitian ini adalah penelitian dan pengembangan (Research and Development) dengan pendekatan kuantitatif. Prosedur penelitian dan pengembangan yang digunakan dalam penelitian ini menggunakan model ADDIE yang meliputi lima tahapan, yakni analysis (analisis), design (desain), development (pengembangan), implementation (implementasi), dan evaluating (evaluasi). Subjek penelitian yang dikaji dalam penelitian ini adalah pengembangan model pembelajaran berbasis karakter konservasi untuk anak usia dini. Sedangkan, objek dalam penelitian ini adalah merupakan ahli model, ahli isi yang berjumlah 2 orang ahli. Teknik yang digunakan dalam mengumpulkan data pada penelitian ini yaitu observasi, wawancara, dan angket. Observasi dilakukan pada pembelajaran guru dan siswa. Wawancara dilakukan pada guru dan orang tua untuk mengetahui perkembangan anak di rumah. Angket digunakan untuk mengumpulkan data yang berkaitan dengan validasi ahli. Instrument yang digunakan dalam mengumpulkan data yaitu kuesioner. Langkah pemberian skor yaitu dengan memberkan tanda centang pada kolom yang telah disediakan dengan rentangan skor 1-5. Hasil uji validitas instrument pada penelitian ini yaitu yang pertama yaitu uji validitas isi pembelajaran dengan skor 1,00 dan uji validitas perorangan dengan skor 1,00 maka kedua uji tersebut memiliki kriteria sangat tinggi. Setelah melakukan uji validitas ke ahli, uji coba lapangan, karena situasi saat ini sedang darurat covid 19 maka penelitian hanya bisa melakukan uji coba perorangan. Teknik yang digunakan untuk menganalisis data yaitu analisis stastistik kualitatif dan kuantitatif. Analisis kualitatif digunakan unuk mengolah data berupa tanggapan, saran, dan kritik. Analisis kuantitatif digunakan untuk menghitung skor yang didapatkan dari para ahli.

\section{Hasil dan Pembahasan}

Pengembangan model pembelajaran berbasis karakter konservasi dilaksanakan dengan menggunakan model penelitian pengembangan ADDIE dengan melalui beberapa tahap yaitu: analisis, perancangan, pengembangan, implementasi, dan evaluasi. Adapun prosedur yang digunakan pada penelitian ini akan dipaparkan sebagai berikut. Pertama, tahap analisis (analyze). Pada tahap ini kegiatan yang dilakukan yaitu analisis kebutuhan siswa, serta permasalahan yang terjadi. Pada tahap ini, data yang diperoleh TK Tunas Harapan Maju ini belum pernah menerapkan model pembelajaran berbasis karakter konservasi, dan di sekolah ini masih banyak anak-anak yang belum paham tentang bagaimana menjaga lingkungan dengan baik, maka dari itu guru merasa sangat perlu mengembangkan model pembelajaran berbasis konservasi agar dapat membentuk anak-anak yang memiliki karakter peduli dan cinta lingkungan. Model pembelajaran berbasis karakter konservasi adalah model pembelajaran yang berprinsip pada pembelajaran karakter yang menunjukkan kepeduliannya terhadap lingkungannya

Tahap kedua, perencanaan (design). Pada tahap kegiatan yang dilakukan yaitu mendesain model pembelajaran berbasis karakter yang disesuaikan dengan anak dalam aktivitas sehari-hari. Tahap desain merupakan tahapan yang berisikan informasi tentang kebutuhan yang diperlukan dalam mengembangkan suatu produk model pembelajaran. Tahapan ini bertujuan untuk perancangan model pembelajaran yang akan dikembangkan, langkah-langkah yang dilakukan pada tahap ini adalah membuat bagan karakteristik model pembelajaran serta rencana pengembangan pembelajaran harian yang akan dikembagkan yang mengacu pada model pembelajaran BCCT (Beyond Center and Circle Time). Model pembelajaran BCCT (Beyond Center and Circle Time) merupakan model yang dianggap sebagai model pembelajaran yang paling tepat bagi anak usia dini karena pembelajarannya berfokus pada anak dan pembelajarannya digunakan di sentra main saat anak dalam lingkaran. Model pembelajaran ini dikembangkan dan ditemukan oleh Dr. Pamela Pheps (seorang tokok pendidikan di Amerika Serikat). Selanjutnya menyusun instrument penilaian, instrumen validasi ahli materi dan ahli isi pembelajaran yang dibuat dalam bentuk angket yang menggunakan tipe jawaban berupa cheklist. Penggunaan cheklist ini digunakan agar peneliti dapat menilai lebih sederhana dan mudah dalam memberikan penilaian. 
Tahap ketiga, pengembangan (development). Pada tahap ini kegiatan yang dilakukan yaitu mengembangkan model pembelajaran berbasis karakter. Model yang dikembangkan berdasarkan rancangan model yang sebelumnya telah dibuat pada tahap desain. Setelah model pembelajaran berbasis karakter konservasi dikembangkan, maka tahap selanjutnya yaitu uji model yang telah dikembangkan akan dilakukan oleh para ahli. Kegiatan ini dilakukan untuk mengetahui kelayakan model yang telah dikembangkan. Tahap implementasi, pada tahap ini, pembelajaran dengan model pembelajaran berbasis karakter konservasi hanya dapat di uji coba perorangan saja pada siswa 3 siswa yang memiliki kemampuan berbeda di kelompok B TK Tunas Harapan Maju Kabupaten Buleleng Tahun Pelajaran 2020/2021 karena situasi darurat covid 19. Tahap evaluasi, tahap evaluasi merupakan tahapan penyempurnaan akhir tentang model pembelajaran yang dikembangkan setelah melalui proses uji coba yang dilakukan. Pada tahap ini tidak ada masukan, saran ataupun komentar dari responden sehingga produk ini dianggap layak untuk digunakan dalam proses pembelajaran. Adapun hasil uji media yang telah dikembangkan oleh para ahli disajikan pada Tabel 1.

Tabel 1. Hasil Uji Model

\begin{tabular}{lccc}
\hline No & \multicolumn{1}{c}{ Ahli } & Persentase & Keterangan \\
\hline 1 & Ahli isi Pembelajaran & $83,70 \%$ & Baik \\
2 & Uji Coba Perorangan & $85,66 \%$ & Sangat Baik \\
\hline
\end{tabular}

Hasil validitas pengembangan model pembelajaran menurut ahli isi pembelajaran yaitu hasil validitasnya adalah 83,70 dengan kategori baik dan hasil uji coba perorangan yaitu hasil validitasnya adalah 85,66 dengan kategori sangat baik sehingga tidak perlu direvisi. Tidak ada komentar, masukan atau saran yang diberikan oleh responden uji coba perorangan. Berdasarkan analisis terhadap masukan, komentar dan saran yang sifatnya revisi pada bagian materi komponen model pembelajaran ada saran yaitu yang pertama agar melengkapi sintaks dan system reaksi sebelum sistem sosial agar komponen menjadi lebih lengkap dan yang kedua yaitu menambahkan penilaian dari aspek bahasa.

Berdasarkan hasil analisis data yang telah dilakukan, bahwa model pembelajaran berbasis karakter konservasi yang dikembangkan layak diterapkan dalam proses pembelajaran. Penelitian pengembangan ini dilakukan untuk mengembangkan produk model pembelajaran berbasis karakter konservasi pada kelompok B TK Tunas Harapan Maju Kabupaten Buleleng tahun ajaran 2020/2021. Produk ini berbentuk model pembelajaran berbasis karakter konservasi yang dapat di implementasikan ketika pembelajaran disekolah. Adapun tahap-tahap yang dilakukan berdasarkan Model Pengembangan ADDIE sebagai berikut: Tahap analisis, pada tahap ini peneliti menganalisis atau mengidentifikasikan kebutuhan dalam mengembangakan suatu model pembelajaran yang perlu di analisis adalah, permasalahan yang ada di tempat penelitian. Hasil analisis yang diperoleh yaitu di TK Tunas Harapan Maju belum pernah menggunakan model pembelajaran yang mampu meningkatkan rasa peduli lingkungan pada anak, sehingga anak-anak masih sering membuang sampah tidak pada tempatnya, mencoret-coret meja, dan tidak mematikan keran setelah menggunakan.

Model pembelajaran berbasis karakter konservasi yang dikembangkan menarik perhatian siswa sehingga membuat siswa termotivasi dalam belajar. Motivasi memiliki peran penting dalam proses pembelajaran anak, adanya motivasi dapat meningkatkan hasil belajar anak (Utari, 2016; Yulianingsih et al., 2020). Model pembelajaran berbasis karakter konservasi memiliki tujuan yang dapat mengembangan aspek perkembangan anak yaitu aspek nilai moral, bahasa, social emosional, dan aspek fisik motorik anak. Mengembangkan aspek nilai moral, dalam proses belajar ini anak sebelum melakukan pembelajaran membaca do"a terlebih dahulu, anak bersikap toleran anak meliputi sabar dalam beajar, dapat memaafkan teman, menerima kesepakatan, dan menghargai teman. Pendidikan nilai-nilai agama dan moral merupakan pondasi yang kokoh dan sangat penting keberadaannya, dan jika hal itu telah tertanam dalam diri anak sejak dini, hal ini merupakan awal yang baik bagi pendidikan anak bangsa untuk menjalani jenjang pendidikan selanjutnya (Ananda, 2017; Nurwita, 2019). Untuk mengembangkan aspek tersebut tentunya dibutuhkan strategi maupun model pembelajaran yang tepat di sekolah atau dirumah.

Selain itu mengembangkan aspek bahasa sangat penting, pembelajaran dengan model pembelajaran berbasis karakter anak mengikuti pembelajaran dengan menyenakan melalui kerjasama dengan teman yang lain. Dengan kerjasama yang ada pada anak aspek perkembangan bahasa anak mengalami kemajuan serta anak senang melakukannya. Pemerolehan bahasa pertama sangat berkaitan dengan perkembangan social anak dan pembentukan identitas sosial. Pemerolehan bahasa pertama seorang anak sangat dipengaruhi oleh lingkungan keluarga di sekitar anak (Suardi et al., 2019). Oleh karena itu bahasa menjadi bagian terpenting dalam pembentukan karakter anak. Model pengembangan pembelajaran berbasis karakter konservasi merupakan salah satu cara untuk mewujudkan pendidikan 
karakter menjadi lebih menyenangkan. Perbedaan model pembelajaran berbasis karakter konservasi hasil pengembangan dengan model pembelajaran sebelumnya terletak pada konservasi yang berkaitan dengan linkungan sekitarnya. Dari pembahasan di atas dapat dipahami bahwa model pembelajaran berbasis karakter konservasi yang dikembangkan layak diterapkan dalam proses pembelajaran merupakan salah satu komponen yang diperlukan TK Tunas Harapan Maju dalam pembelajaran karakter anak usia dini. Temuan yang ada menunjukkan bahwa pengembangan model ini mendapat kualifikasi baik. Kajian ini dapat dijadikan sebagai evaluasi dalam perencanaan pendidikan karakter untuk anak usia dini, sehingga pendidikan karakter dapat terlaksana dengan optimal.

\section{Simpulan}

Pengembangan model pembelajaran berbasis karakter konservasi menunjukkan kualitas yang baik dan layak digunakan untuk meningkatkan pemahaman anak usia dini tentang pentingnya karakter konservasi atau peduli lingkungan dapat memberikan inovasi baru terhadap guru dalam mengembangkan karakter peduli lingkungan pada peserta didik. Keterbatan pengembangan model pembelajaran berbasis karakter konservasi tidak dapat dilaksanakan pada tahap implementasi, direkomendasikan penelitian selanjutnya dapat menerapkan model ini melalui penelitian eksperimen. Implikasi penelitian ini diharapkan memberikan dampak pada karakter anak menjadi lebih baik.

\section{Daftar Rujukan}

Amalia, A. V., \& Bintari, S. H. (2016). Penerapan Model Picture and Picture Pada Pembelajaran. Unnes Science Education Journal, 5(1), 1116-1122. https://doi.org/10.15294/USEJ.V5I1.9644.

Ananda, R. (2017). Implementasi Nilai-nilai Moral dan Agama pada Anak Usia Dini. Jurnal Obsesi : Jurnal Pendidikan Anak Usia Dini, 1(1), 19. https://doi.org/10.31004/obsesi.v1i1.28.

Ansori, Y. Z. (2021). Strategi Pendidik dalam Menumbuhkan Karakter Jujur pada Anak Usia Dini. Jurnal Obsesi: Jurnal Pendidikan Anak Usia Dini, 6(1), 261-270. https://doi.org/10.31004/obsesi.v6i1.1208.

Hidayah, N. (2015). Penanaman Nilai-nilai Karakter Dalam Pembelajaran Bahasa Indonesia di Sekolah Dasar. Jurnal Pendidikan Dan Pembelajaran Dasar, 2(2). https://doi.org/10.24042/terampil.v2i2.1291.

Juanda, J. (2019). Pendidikan Karakter Anak Usia Dini melalui Sastra Klasik Fabel Versi Daring. Jurnal Obsesi : Jurnal Pendidikan Anak Usia Dini, 3(1), 39. https://doi.org/10.31004/obsesi.v3i1.126.

Khusniati, M. (2014). Model Pembelajaran Sains Berbasis Kearifan Lokal Dalam Menumbuhkan Karakter Konservasi. Indonesian Journal of Conservation, 3(1), 67-74. https://doi.org/10.15294/ijc.v3i1.3091.

Leksono, S. M., Rustaman, N., \& Redjeki, S. (2013). Kemampuan Profesional Guru Biologi Dalam Memahami Dan Merancang Model Pembelajaran Konservasi Biodiversitas Di Sma. Jurnal Cakrawala Pendidikan, 3(3), 408-419. https://doi.org/10.21831/cp.v3i3.1628.

Muhamad Nova. (2017). Character Education In Indonesia EFL Classroom Implementation and Obstacles. Jurnal Pendidikan Karakter, 7(2). https://doi.org/10.21831/jpk.v7i2.13650.

Na'imah, T., Widyasari, Y., \& Herdian, H. (2020). Implementasi Sekolah Ramah Anak untuk Membangun Nilai-Nilai Karakter Anak Usia Dini. Jurnal Obsesi: Jurnal Pendidikan Anak Usia Din, 4(2), 747-756. https://doi.org/10.31004/obsesi.v4i2.283.

Nurohmah, A. N., \& Dewi, D. A. (2021). Penanaman Nilai Moral dan Karakter di Era Pandemi melalui Pendidikan dengan Mengimplementasikan Nilai-Nilai Pancasila. Journal of Education, Psychology and Counseling, 3(1), 119-128. https://ummaspul.e-journal.id/Edupsycouns/article/view/1305.

Nurwita, S. (2019). Analisis Nilai-Nilai Agama dan Moral Anak Usia Dini dalam Tayangan Film Kartun Upin dan Ipin. Jurnal Obsesi : Jurnal Pendidikan Anak Usia Dini, 3(2), 506. https://doi.org/10.31004/obsesi.v3i2.252.

Pitaloka, D. L., Dimyati, D., \& Edi, P. (2021). Peran Guru dalam Menanamkan Nilai Toleransi pada Anak Usia Dini di Indonesia. Jurnal Obsesi: Jurnal Pendidikan Anak Usia Dini, 5(2), 1696-1705. https://doi.org/10.31004/obsesi.v5i2.972.

Prasanti, D., \& Fitrianti, D. R. (2018). Pembentukan Karakter Anak Usia Dini: Keluarga, Sekolah, Dan Komunitas. Pembentukan Anak Usia Dini : Keluarga, Sekolah, Dan Komunitas, 2(1), 15.

Purnomo, P., \& Sukarjo, A. (2020). Penerapan Model Pembelajaran Tanggung Jawab Pribadi dan Sosial Berbasis Lesson Study untuk Menguatkan Karakter Konservasi dan Meningkatkan Hasil Belajar. Jurnal Kreatif: Jurnal Kependidikan 100-116. https://journal.unnes.ac.id/nju/index.php/kreatif/article/viewFile/23603/10077.

Ramdan, A. Y., \& Fauziah, P. Y. (2019). Peran orang tua dan guru dalam mengembangkan nilai-nilai karakter anak usia sekolah dasar. Jurnal Pendidikan Dasar Dan Pembelajaran, 9(2), 100. 
https://doi.org/10.25273/pe.v9i2.4501.

Ramdhani, S., Yuliastri, N. A., Sari, S. D., \& Hasriah, S. (2019). Penanaman Nilai-Nilai Karakter melalui Kegiatan Storytelling dengan Menggunakan Cerita Rakyat Sasak pada Anak Usia Dini. Jurnal Obsesi : Jurnal Pendidikan Anak Usia Dini, 3(1), 153. https://doi.org/10.31004/obsesi.v3i1.108.

Ridlo, S., \& Irsadi, A. (2012). Pengembangan Nilai Karakter Konservasi Berbasis Pembelajaran. Jurnal Penelitian Pendidikan Unnes, 29(2), 124062. https://doi.org/10.15294/jpp.v29i2.5657.

Rohmanurmeta, M. . \& D. . (2019). Pengembangan Komik Digital Pelestarian Lingkungan Berbasis Nilai Karakter Religi Untuk Pembelajaran Tematik pada Siswa Sekolah Dasar. MUADDIB: Studi Kependidikan Dan Keislaman, 9(02), 131-141. https://doi.org/10.24269/muaddub.v11i2.1213.

Rosikum, R. (2018). Pola Pendidikan Karakter Religius pada Anak melalui Peran Keluarga. Jurnal Kependidikan, 6(2). https://doi.org/https://doi.org/10.24090/jk.v6i2.1910.

Sadia, W. (2013). Model Pendidikan Karakter Terintegrasi Pembelajaran Sains. JPI (Jurnal Pendidikan Indonesia), 2(2), 209-220. https://doi.org/10.23887/jpi-undiksha.v2i2.2165.

Suardi, I. P., Ramadhan, S., \& Asri, Y. (2019). Pemerolehan Bahasa Pertama pada Anak Usia Dini. Jurnal Obsesi : Jurnal Pendidikan Anak Usia Dini, 3(1), 265. https://doi.org/10.31004/obsesi.v3i1.160.

Syahrul, \& Nurhafizah. (2021). Analisis Pengaruh Pola Asuh Orang Tua Terhadap Perkembangan Sosial dan Emosional Anak Usia Dini Dimasa Pandemi Corona Virus 19. Jurnal Basicedu, 5(2), 683-696. https://doi.org/10.31004/basicedu.v5i2.792.

Taufiq, M., Dewi, N. R., \& Widiyatmoko, A. (2014). Pengembangan media pembelajaran ipa terpadu berkarakter peduli lingkungan tema "konservasi" berpendekatan science-edutainment. Jurnal Pendidikan IPA Indonesia, 3(2), 140-145. https://doi.org/10.15294/jpii.v3i2.3113.

Utari, R. (2016). Kontribusi Motivasi Belajar Dan Kebiasaan Belajar Siswa Kelas 1 Teknik Audio Video Terhadap Hasil Belajar Pada Mata Diklat Pkdle Di Smk N 1 Padang. Jurnal Ilmiah Pendidikan Teknik Elektro, 1(oktober 2016), 108-114. https://doi.org/http://dx.doi.org/10.30870/volt.v1i2.2877.

Wisnu Budi Wijaya, I. K. (2019). Menanamkan Konsep Catur Paramita Pada Anak Usia Dini Di Lingkungan Keluarga Dan Sekolah. Pratama Widya: Jurnal Pendidikan Anak Usia Dini, 3(2), 41-46. https://doi.org/10.25078/pw.v3i2.737.

Yulianingsih, W., Suhanadji, S., Nugroho, R., \& Mustakim, M. (2020). Keterlibatan Orangtua dalam Pendampingan Belajar Anak selama Masa Pandemi Covid-19. Jurnal Obsesi : Jurnal Pendidikan Anak Usia Dini, 5(2), 1138-1150. https://doi.org/10.31004/obsesi.v5i2.740.

Yulianti, D., S, R., H, S., \& Diana, D. (2014). Pengembangan Karakter Peduli Lingkungan Anak Usia Dini Melalui Buku Cerita Bermuatan Sains Berwawasan Konservasi. Jurnal Penelitian Pendidikan Unnes, 31(1), 124422. https://doi.org/10.15294/jpp.v31i1.5681. 